\title{
Use of dewatered sludge as microbial inoculum of a subsurface wastewater infiltration system: effect on start-up and pollutant removal
}

\author{
Yingying Jiang ${ }^{1 "}$, Yafei Sun"1, Jing Pan ${ }^{1 * *}$ and Yang Zhang ${ }^{1}$ \\ ${ }^{1}$ College of Life Science, Shenyang Normal University, 253, Huanghe Street, Shenyang 110034, China
}

\begin{abstract}
Brown earth-based subsurface wastewater infiltration systems (SWISs) inoculated with/without dewatered sludge were constructed and operated under the same conditions to boost the application of SWIS in brown soil areas. Start-up period of SWIS with dewatered sludge was 28 days, 12 days shorter than that of SWIS without dewatered sludge. $\mathrm{COD}, \mathrm{NH}_{3}-\mathrm{N}$ and TN removal efficiencies of dewatered sludge as microbial inoculum for SWIS were higher than that of SWIS without dewatered sludge under hydraulic loading rates (HLR) of $0.04,0.07,0.1$ and $0.13 \mathrm{~m}^{3} \cdot \mathrm{m}^{-2} \cdot \mathrm{d}^{-1}$. Effluent concentrations of $\mathrm{COD}, \mathrm{NH}_{3}-\mathrm{N}$ and TN in the SWIS inoculated with dewatered sludge were $44.51 \pm 4.13,7.35 \pm 0.24$ and $14.03 \pm 0.31 \mathrm{mg} \cdot \mathrm{L}^{-1}$ under HLR of $0.13 \mathrm{~m}^{3} \cdot \mathrm{m}^{-2} \cdot \mathrm{d}^{-1}$, which were simultaneously lower than Chinese criteria for water discharge from municipal wastewater treatment plants. The number of bacteria, nitrifying bacteria and denitrifying bacteria in dewatered sludge as microbial inoculum for SWIS were higher than that in SWIS without dewatered sludge under the same HLR. The results will be helpful in promoting the application of dewatered sludge as microbial inoculum in brown earth-based SWISs for the purpose of shortening start-up period, effecting high levels of pollutant removal and recycling waste.
\end{abstract}

Keywords: subsurface wastewater infiltration system, dewatered sludge, start-up, inoculum

\section{INTRODUCTION}

Decentralized wastewater treatment is becoming ever more critical because $95 \%$ of decentralized wastewater around the world is currently discharged into the environment without any treatment (Li et al., 2011b). Subsurface wastewater infiltration systems (SWIS) are an effective way to treat decentralized wastewater according to integrated mechanisms of chemical, physical and biological reactions, as it passes through the unsaturated soil in the infiltration system (Fan et al., 2013) SWIS has many advantages compared with conventional wastewater treatment plants, including high removal efficiency for organics and phosphorus, low construction and operation cost and easy maintenance (Li et al., 2011a). It is widely used in North America, Europe and Asia (Li et al., 2011b). The maximum wastewater hydraulic loading rate of SWIS differs across locations because of differences in the soil matrix and degree of pre-treatment. In China and Japan, a maximum wastewater hydraulic loading rate of $0.1 \mathrm{~m}^{3} \cdot \mathrm{m}^{-2} \cdot \mathrm{d}^{-1}$ is recommended. There are no general recommendations for the maximum number of inhabitants for the application of SWIS. In China, the maximum number of inhabitants for the application of SWIS $\left(800 \mathrm{~m}^{3} \cdot \mathrm{d}^{-1}\right)$ is reported by Li et al. (2012) to be 8000 (Li et al., 2012).

Over the past 20 years, SWISs have gained popularity in villages and small communities, and in rural areas. In these parts there is enough land for building SWISs. The infiltration beds can be planted with grass and shallow-rooted plants. Whether the SWIS method is suitable depends on local wastewater volumes and landscape surface, etc. The soil matrix is an important component which can ensure high removal efficiencies with limited operational and maintenance

\# These authors contributed equally to this study and share first authorship

* To whom all correspondence should be addressed.

巡 +278624 86593328; fax: +27 8624 86592584; e-mail: crystalpan78@126.com

Received 17 June 2016, accepted in revised form 6 October 2017 requirements at relatively low cost (Li et al., 2013). Brown earth is the major soil in areas with warm and humid climates. Since brown earth has low permeability, which is unsuitable as a sole filtration medium for SWIS, coal slag is added as the main modifying material (Li et al., 2011b; 2013). However, many previous studies have shown that brown earth and coal slagbased SWIS could not meet the required hydraulic loading rate (HLR) related to an increase in population size (Li et al., 2011a; 2013). Removal performance was generally satisfactory at a low HLR of $0.01-0.08 \mathrm{~m}^{3} \cdot \mathrm{m}^{-2} \cdot \mathrm{d}^{-1}$ (Llorens et al., 2011), but declined significantly under high $\operatorname{HLR}\left(0.1 \mathrm{~m}^{3} \cdot \mathrm{m}^{-2} \cdot \mathrm{d}^{-1}\right)$ (Li et al., 2012). The hydraulic and purification behaviour of the SWIS can be determined from system matrix features, operational parameters and environmental conditions (Zou et al., 2009). Moreover, unlike the excellent performance for organic and phosphorus removal, $\mathrm{NH}_{3}-\mathrm{N}$ and $\mathrm{TN}$ removal efficiencies lower than $60 \%$ and $40 \%$ have been recorded in conventional brown earth and coal slag-based SWIS (Li et al., 2011c; Wang et al., 2010).

Nitrification coupled with denitrification is the major removal process for nitrogen in SWIS. Nitrification and denitrification is usually affected by the nitrifying and denitrifying biomass, temperature, operational parameters and the characteristics of the matrix (Zou et al., 2009). Conventional SWIS combined with bioaugmentation for improving the pollutant removal efficiencies is an interesting possibility (Zou et al., 2009; Li et al., 2013). Bioaugmentation can be explained as a process by which the indigenous or wild type or genetically-modified organism is added to the bioreactor or to the polluted sites in order to improve the performance of the biological processes (Lee et al., 2007).

Wastewater sludge is a heterogeneous mixture of particles, micro-organisms, colloids and cations, the treatment and reuse of which is a challenging issue for water industries. Nevertheless, very few published studies have focused on wastewater sludge as microbial inoculum of the SWIS matrix to enhance removal performance. The main purpose of this study was as follows: (i) to assess the start-up performance in two 
pilot-scale brown earth-based SWISs inoculated with/without dewatered sludge, (ii) to identify the effect of dewatered sludge as microbial inoculum on pollutant removal under different HLRs, and (iii) to explore the microbial quantities involved in pollutant removal in two SWIS.

\section{METHODS}

\section{System description}

Two pilot-scale SWIS (A and B), made of plexiglass, were constructed in Shenyang Normal University in Shenyang, Northeast China (Fig. 1). The systems were $1.2 \mathrm{~m}$ in length and $0.5 \mathrm{~m}$ in internal diameter. $10 \mathrm{~cm}$ of gravel $(10-20 \mathrm{~mm}$, diameter) was prepared at the bottom to support the infiltration system and evenly distribute the treated water. A distributing pipe was installed at a depth of $50 \mathrm{~cm}$ below the surface. Sampling ports were installed at 50,80 and $110 \mathrm{~cm}$ from the top of the SWIS to assess the microbial quantities involved in the pollutant removal process. The feed tank was placed at a higher position so that influent could flow automatically into the SWIS. The treated wastewater was collected at the bottom of the column near the outlet. SWIS A was filled with $95 \%$ brown earth and $5 \%$ coal slag by weight. SWIS B was filled with $85 \%$ brown earth, $5 \%$ coal slag and $10 \%$ dewatered sludge by weight. The optimum ratios of brown earth, coal slag and dewatered sludge were determined in a preliminary experiment. Under this experimental condition, the removal performance of the SWIS was better than for other ratios. Dewatered sludge was collected from the sludge-dewatering unit of the $\mathrm{Bei} \mathrm{Bu}$ Wastewater Treatment Plant located in Huanggu District, Shenyang, China. The brown earth was collected from the top $20 \mathrm{~cm}$ of soil at Shenyang Ecological Station. Coal slag, an inorganic waste produced in coal combustion, is composed of $\mathrm{SiO}_{2} 33.95 \mathrm{mg} \cdot \mathrm{kg}^{-1}, \mathrm{Al}_{2} \mathrm{O}_{3} 3.89 \mathrm{mg} \cdot \mathrm{kg}^{-1}, \mathrm{CaO} 2.80 \mathrm{mg} \cdot \mathrm{kg}^{-1}$ and $\mathrm{MgO} 4.82 \mathrm{mg} \cdot \mathrm{kg}^{-1}$. The matrix components were mixed in a blender 5 times for $15 \mathrm{~min}$ to ensure uniformity of the matrix. The physical characteristics of the matrix in SWIS A and SWIS $\mathrm{B}$ before the experiments began are shown in Table 1. The soil matrix in each SWIS was water-unsaturated.

After settling pre-treatment, the wastewater from Shenyang Normal University Campus was pumped into the SWIS. The concentration ranges of wastewater after pre-treatment were pH 6.7-7.5, COD 185.3-262.4 mg. $\mathrm{L}^{-1}$, TN 37.9-41.7 mg. $\mathrm{L}^{-1}$, TP 4.6-6.3 mg. $\mathrm{L}^{-1}$, and $\mathrm{NH}_{3}-\mathrm{N} 32.3-38.6 \mathrm{mg} \cdot \mathrm{L}^{-1}$. Intermittent operation was adopted in this study, and each cycle of the intermittent operation included a flooding period of $24 \mathrm{~h}$ and a drying period of $24 \mathrm{~h}$. Two SWIS were operated under an HLR of $0.04 \mathrm{~m}^{3} \cdot \mathrm{m}^{-2} \cdot \mathrm{d}^{-1}$ for start-up; after start-up, two SWIS were operated under four processes, with the HLR gradually elevated from 0.04 to $0.07,0.1$ and $0.13 \mathrm{~m}^{3} \cdot \mathrm{m}^{-2} \cdot \mathrm{d}^{-1}$. Each process lasted for 30 days.

\section{Sampling and analytical methods}

Water samples were taken from the influent and effluent to analyse the transformation of $\mathrm{COD}, \mathrm{TP}, \mathrm{NH}_{3}-\mathrm{N}$ and $\mathrm{TN}$, according to standard methods (APHA, 2003). Matrix samples were collected from sampling ports during the experiment. Nutrient agar medium was used to culture bacteria by plate counts. The nitrifying and denitrifying bacteria in the soil matrix samples were counted using the most probable number (MPN) calculation (Alexander and Clark, 1965) once per week. One millilitre of serial tenfold sterile dilutions of the

\begin{tabular}{|l|c|c|}
\hline \multicolumn{3}{|c|}{ TABLE 1 } \\
Main characteristics of the matrices in two SWISs \\
\hline Item & SWIS A & SWIS B \\
\hline $\begin{array}{l}\text { Hydraulic conductivity } \\
\left(\mathrm{cm} \cdot \mathrm{s}^{-1}\right)\end{array}$ & $(1.35 \pm 0.3) \times 10^{-3}$ & $(1.54 \pm 0.1) \times 10^{-3}$ \\
\hline Surface area $\left(\mathrm{m}^{2} \cdot \mathrm{kg}^{-1}\right)$ & $132.6 \pm 4.2$ & $224.5 \pm 7.4$ \\
\hline BN & $(3.8 \pm 0.4) \times 10^{4}$ & $(4.7 \pm 0.3) \times 10^{5}$ \\
\hline NBN & $(4.8 \pm 0.3) \times 10^{2}$ & $(3.4 \pm 0.8) \times 10^{4}$ \\
\hline DBN & $(6.1 \pm 0.2) \times 10$ & $(2.9 \pm 0.6) \times 10^{5}$ \\
\hline
\end{tabular}

$B N$ : bacteria number $\left(c f u \cdot g^{-1}\right) ; N B N$ : nitrifying bacteria number $\left(c f u \cdot g^{-1}\right)$; $D B N$ : denitrifying bacteria number $\left(c f u \cdot g^{-1}\right)$.

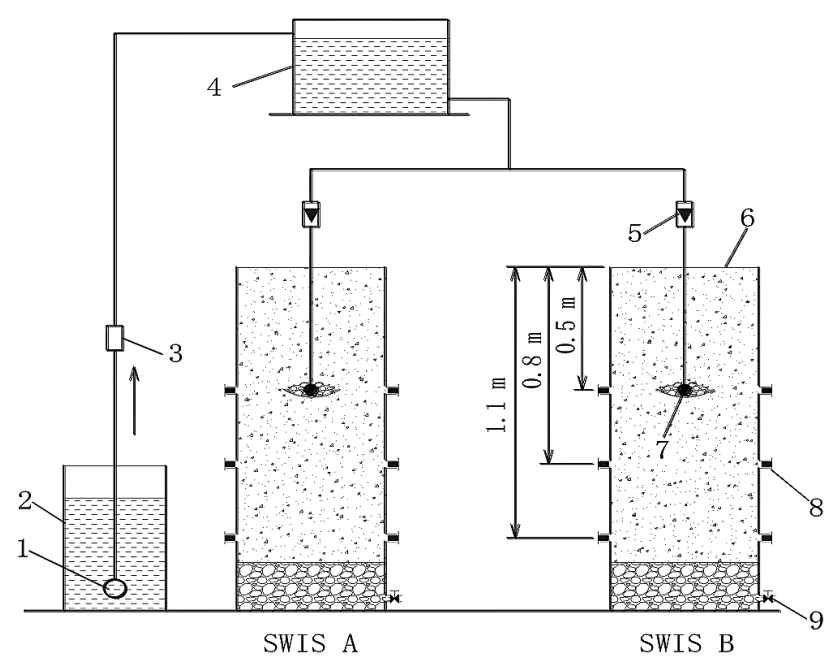

Figure 1

Schematic diagram of two subsurface wastewater infiltration systems (1) submerged pump; (2) wastewater tank; (3) control valve; (4) high-level tank; (5) flow meter; (6) infiltration system body; (7) distributing pipe; (8) sample port; (9) outlet

soil samples were transferred to test tubes containing the appropriate medium under aseptic conditions, then incubated at $28^{\circ} \mathrm{C}$ for $14 \mathrm{~d}$ (for the nitrifying bacteria) and $15 \mathrm{~d}$ (for the denitrifying bacteria), respectively. The medium for the nitrifying bacteria contained, per litre of distilled water: $13.5 \mathrm{~g} \mathrm{Na}_{2} \mathrm{HPO}_{4}, 0.7 \mathrm{~g} \mathrm{KH}_{2} \mathrm{PO}_{4}, 0.1 \mathrm{~g} \mathrm{MgSO}_{4}, 0.5 \mathrm{~g} \mathrm{NaHCO}_{3}$,

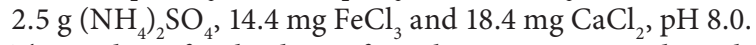
The medium for the denitrifying bacteria contained, per litre of distilled water: $1.0 \mathrm{~g} \mathrm{KNO}_{3}, 0.1 \mathrm{~g} \mathrm{Na}_{2} \mathrm{HPO}_{4}, 2.0 \mathrm{~g} \mathrm{Na}_{2} \mathrm{~S}_{2} \mathrm{O}_{7}$, $0.1 \mathrm{~g} \mathrm{NaHCO}_{3}$ and $0.1 \mathrm{~g} \mathrm{MgCl}_{2}$, at $\mathrm{pH}$ 8.0. MPN analysis was performed using statistical tables from Alexander and Clark (1965). All samples were taken to the laboratory and analysed immediately. All analyses were conducted in triplicate.

\section{RESULTS AND DISCUSSION}

\section{Start-up of two SWIS}

Figure 2 shows the pollutant removal performance for two SWIS during the start-up period. The start-up period can be divided into two different phases: Phase 1 for the first 5 days and Phase 2 for the days that follow. Effluent COD, $\mathrm{NH}_{3}-\mathrm{N}$ and $\mathrm{TN}$ concentrations for the two SWIS gradual decreased from Day 1 to Day 3, which can be ascribed to the adsorption capacity of the matrix. However, effluent COD, $\mathrm{NH}_{3}-\mathrm{N}$ and TN concentrations increased on Day 5 in Phase 
1. This was because the matrix adsorption reached saturation and adsorbed pollutants began to be released. SWIS B had higher pollutant adsorption capacity than SWIS A, due to SWIS B having a higher surface area than SWIS A (Table 1). The performances of the two SWIS generally became stable in Phase 2 and effluent $\mathrm{COD}, \mathrm{NH}_{3}-\mathrm{N}$ and TN concentrations gradual decreased because of microbial biofilm formation on the matrix. Organic matter and nitrogen are absorbed by the soil, and then broken down by aerobic and anaerobic microbial processes (Fan et al., 2013). Matrix adsorption would be the dominant process for removal of $\mathrm{COD}, \mathrm{NH}_{3}-\mathrm{N}$ and $\mathrm{TN}$ at the beginning of operation, and the role of adsorption would gradually be replaced by the activity of nitrifying and denitrifying bacteria, as there was a smooth rate of increase in the quantity of microorganisms in the SWIS (Li et al., 2013; Yang et al., 2016). From the beginning of the experiment, effluent TP concentration in the two SWIS was below the levels prescribed by Chinese criteria for water discharge from municipal wastewater treatment plants. Phosphorus removal mechanisms include physical sedimentation, chemical adsorption and precipitation, and biological processes (plant and microbial uptake) in the soil (Li et al., 2011b). Physical sedimentation and chemical adsorption are the main methods of phosphorus removal in
SWIS, which could be completed instantaneously (Brooks et al., 2000). After 33 days of operation, effluent COD, $\mathrm{NH}_{3}-\mathrm{N}$ and TN concentrations in SWIS A were simultaneously lower than the above-mentioned Chinese limits of $50 \mathrm{mg} \cdot \mathrm{L}^{-1}$, $8 \mathrm{mg} \cdot \mathrm{L}^{-1}$ and $15 \mathrm{mg} \cdot \mathrm{L}^{-1}$, respectively; this was achieved in only 21 days in SWIS B. Standards for the start-up period in a SWIS are not conclusive. It is generally accepted that the system has achieved stable operation 1 week after the effluent reaches the corresponding discharge standards, which marks the end of the start-up period (Li et al., 2013). Therefore, the start-up period of SWIS A was 40 days, but was only 28 days for SWIS B. After the start-up period, pollutant removal performance of SWIS B were better than SWIS A. These results were attributed to the fact that SWIS B had more bacteria, including nitrifying bacteria and denitrifying bacteria, than SWIS A (in Table 1). Due to the differences in the composition of the matrix, different adaptive behaviours may have been expressed resulting in the SWIS inoculated with dewatered sludge developing a biofilm more quickly than the SWIS inoculated without dewatered sludge (Li et al., 2013; Yang et al., 2016). A rapidly developed biofilm may be beneficial in full-scale applications by hastening start-up. Therefore, the dewatered sludge was a good microbial inoculum to the brown earth-based SWIS in light of the shortened start-up period.
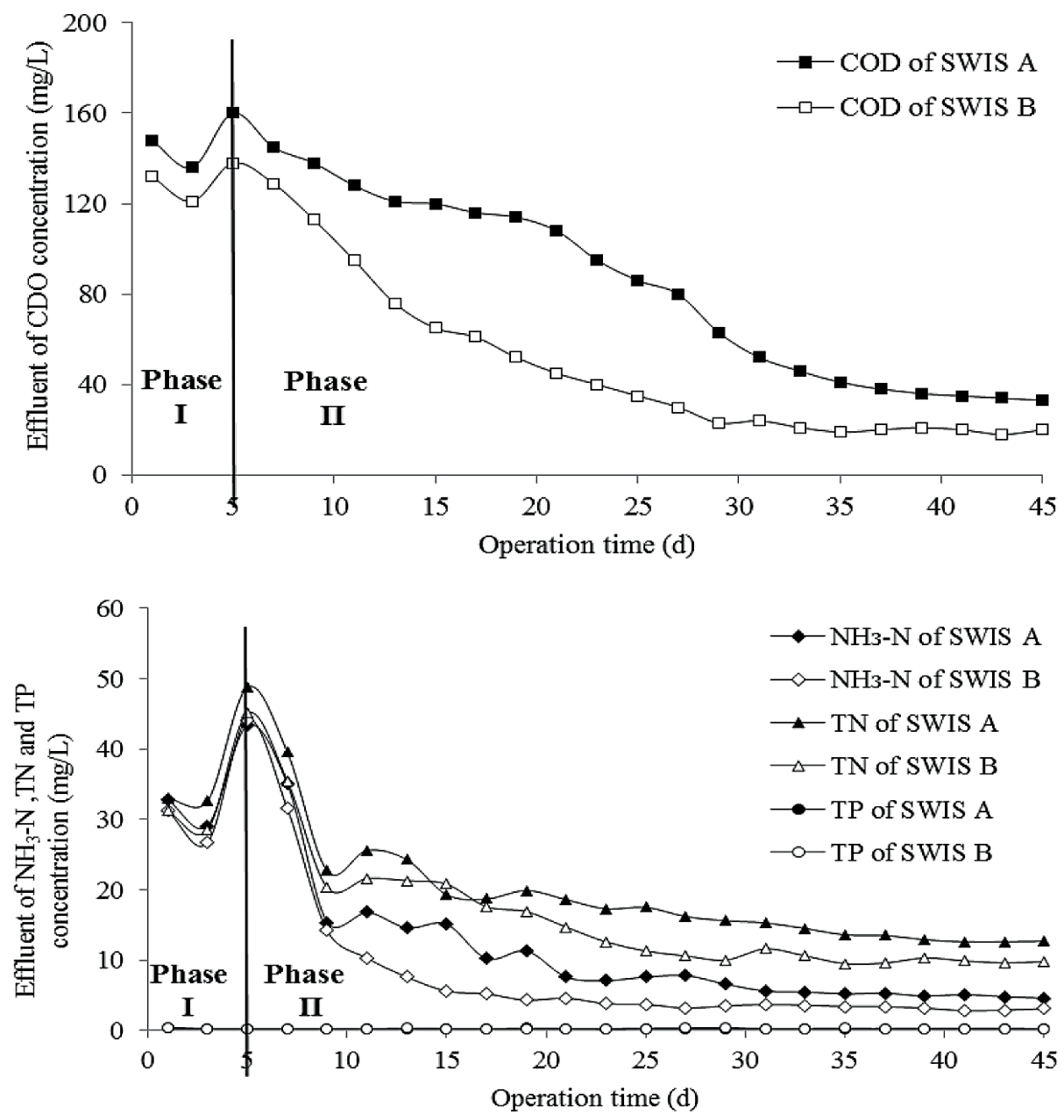

Figure 2

Pollutant removal SWIS A and SWIS B during start-up period 


\section{Pollutant removal and main microbial community of two SWIS under different HLRs}

In this study, HLR of $0.04,0.07,0.10$ and $0.13 \mathrm{~m}^{3} \cdot \mathrm{m}^{-2} \cdot \mathrm{d}^{-1}$ were presented to test the effects of HLR on pollutant removal in two brown earth-based SWISs inoculated with/without dewatered sludge. HLR is an important factor influencing the performance of a soil treatment system (Zou et al., 2009). Relatively high loading rates could not maintain stable operation of the system over the long term; keeping loading rates relatively low would require that more soil is used. As seen from Table 2, COD removal efficiencies for SWIS A and SWIS B dropped dramatically from $85.22 \pm 2.36 \%$ and $92.99 \pm 1.57 \%$ under HLR of $0.04 \mathrm{~m}^{3} \cdot \mathrm{m}^{-2} \cdot \mathrm{d}^{-1}$ to $68.37 \pm 2.34 \%$ and $80.88 \pm 1.24 \%$ under $0.13 \mathrm{~m}^{3} \cdot \mathrm{m}^{-2} \cdot \mathrm{d}^{-1}$, respectively. The observation indicated that hydraulic loadings affected COD removal in the following ways: Firstly, increasing hydraulic loading rates leads to a requirement for more matrix surfaces. Secondly, increasing hydraulic loading rates means shortening hydraulic retention time, so that organic matter is not fully degraded. TP removal efficiencies slightly decreased with increased HLR in SWIS A and SWIS B. A possible explanation might be that longer hydraulic retention time was achieved under lower HLR, which increased the exposure time and exposed new or hidden sorption/precipitation agents in the matrix (Yang et al., 2016). Effluent TP concentrations in the two SWIS were below wastewater discharge limits under HLR of $0.04,0.07,0.10$ and $0.13 \mathrm{~m}^{3} \cdot \mathrm{m}^{-2} \cdot \mathrm{d}^{-1}$.

In a SWIS, $\mathrm{NH}_{3}-\mathrm{N}$ is adsorbed onto the surface of soil particles with negative charges, and then transformed into nitrate nitrogen via microbial nitrification. Nitrification occurs only when oxygen is present at a high enough concentration to support the growth of strictly aerobic nitrifying bacteria (Li et al., 2011b). The removal efficiencies for $\mathrm{NH}_{3}-\mathrm{N}$ declined from $83.01 \pm 1.59 \%$ under HLR of $0.04 \mathrm{~m}^{3} \cdot \mathrm{m}^{-2} \cdot \mathrm{d}^{-1}$ to $62.79 \pm 0.64 \%$ under HLR of $0.13 \mathrm{~m}^{3} \cdot \mathrm{m}^{-2} \cdot \mathrm{d}^{-1}$ for SWIS A and from $91.64 \pm 0.64 \%$ under HLR of $0.04 \mathrm{~m}^{3} \cdot \mathrm{m}^{-2} \cdot \mathrm{d}^{-1}$ to $79.53 \pm 0.17 \%$ under HLR of $0.13 \mathrm{~m}^{3} \cdot \mathrm{m}^{-2} \cdot \mathrm{d}^{-1}$ for SWIS B. When the HLR increased to $0.13 \mathrm{~m}^{3} \cdot \mathrm{m}^{-2} \cdot \mathrm{d}^{-1}$, soil clogging occurred in brown earth and coal slag-based SWIS and resulted in the marked elevation of $\mathrm{NH}_{3}-\mathrm{N}$ concentrations in the effluent ( $\mathrm{Li}$ et al., 2011a). Clogging prevented oxygen from diffusing into the soil matrix and lower oxygen levels caused the insufficient transformation from $\mathrm{NH}_{3}-\mathrm{N}$ to $\mathrm{NO}_{2}-\mathrm{N}$ or $\mathrm{NO}_{3}-\mathrm{N}$ in SWIS A. Nitrogen removal mechanisms in the SWIS include grass uptake, soil fixation, ammonia volatilization, nitrification and denitrification, etc. (Pan et al., 2015). Nitrification coupled with denitrification is the major pathway and nitrification is the limiting step for nitrogen removal. Therefore, TN removal efficiency decreased with an increase in HLR, due to limited nitrification under higher HLR. This result was inconsistent with previous studies, which found that removal efficiency for $\mathrm{NH}_{3}-\mathrm{N}$ and $\mathrm{TN}$ decreased with an increase in HLR (Li et al., 2012; Zou et al., 2009).

As seen from Table 2, COD, $\mathrm{NH}_{3}-\mathrm{N}$ and TN removal efficiencies for SWIS B were higher than for SWIS A under HLR of $0.04,0.07,0.1$ and $0.13 \mathrm{~m}^{3} \cdot \mathrm{m}^{-2} \cdot \mathrm{d}^{-1}$. Effluent COD, $\mathrm{NH}_{3}-\mathrm{N}$ and TN concentrations in SWIS A under HLR of 0.1 and $0.13 \mathrm{~m}^{3} \cdot \mathrm{m}^{-2} \cdot \mathrm{d}^{-1}$ were simultaneously higher than wastewater discharge criteria. However, SWIS B maintained low effluent pollutant concentrations under an HLR of $0.13 \mathrm{~m}^{3} \cdot \mathrm{m}^{-2} \cdot \mathrm{d}^{-1}$. The results imply that it was the dewatered sludge that had increased the pollutant removal performances. Many other studies have reported a maximum HLR of $0.08 \mathrm{~m}^{3} \cdot \mathrm{m}^{-2} \cdot \mathrm{d}^{-1}$ for brown earth and coal slag-based SWISs to treat domestic wastewater (Li et al., 2011a; 2012; 2013). Compared with previous research, the hydraulic loading capacity of SWIS B was relatively higher, due to the use of dewatered sludge as microbial inoculum. This practice had further advantages in possessing abundant microbes, high hydraulic conductivity and supplying a substantial adsorption surface area (Li et al., 2013). The removal performance and operational lifetime of the infiltration system was dependent on the accumulation of biofilms within the void spaces (Li et al., 2013). Inoculation with dewatered sludge produces a high biomass concentration (Kizikaya et al., 2008). Therefore, the start-up period was shortened when using dewatered sludge as microbial inoculum, hydraulic loading capacity was increased and $\mathrm{COD}, \mathrm{NH}_{3}-\mathrm{N}$ and TN removal efficiencies were enhanced simultaneously.

The microbial quantities involved in pollutant removal were analysed during the experiment. As seen from Fig. 3, the number of bacteria of each layer in the matrix increased 10 -fold when HLR increased by $0.03 \mathrm{~m}^{3} \cdot \mathrm{m}^{-2} \cdot \mathrm{d}^{-1}$ in the range of $0.04 \mathrm{~m}^{3} \cdot \mathrm{m}^{-2} \cdot \mathrm{d}^{-1}-0.10 \mathrm{~m}^{3} \cdot \mathrm{m}^{-2} \cdot \mathrm{d}^{-1}$ in two SWISs. Under low HLR, it is likely that bacterial growth and reproduction was limited by nutrient supply. The number of bacteria in each layer of the matrix decreased 10 -fold, when HLR increased from $0.10 \mathrm{~m}^{3} \cdot \mathrm{m}^{-2} \cdot \mathrm{d}^{-1}$ to $0.13 \mathrm{~m}^{3} \cdot \mathrm{m}^{-2} \cdot \mathrm{d}^{-1}$ in two SWIS. Under the high HLR, retention time of wastewater was short and partial matrix was saturated, which did not favour the growth and reproduction of bacteria (Li et al., 2011a; 2012). Organic pollutants in the influent are mainly oxidized in the upper matrix, given sufficient oxygen in the infiltration system, by bacteria, fungus, actinomyces and protozoans, etc. (Hsieh et al., 2007; Yang et al., 2016). In this study, COD removal efficiency was consistent with the change in bacterial

\begin{tabular}{|c|c|c|c|c|c|c|c|c|}
\hline & Effluent cha & aracteristics a & e & $\begin{array}{l}\text { TABLE } 2 \\
\text { iencies in } 5\end{array}$ & and SW & nder diff & HLRs & \\
\hline I R & 0.04 & $1^{-2} \cdot d^{-1}$ & 0.0 & $n^{-2} \cdot d^{-1}$ & 0.10 & $n^{-2} \cdot d^{-1}$ & $0.13 \mathrm{~m}^{3}$ & $m^{-2} \cdot d^{-1}$ \\
\hline W & SWIS A & SWIS B & SWIS A & SWIS B & SWIS A & SWIS B & SWIS A & SWIS B \\
\hline COD $\left(\mathrm{mg} \cdot \mathrm{L}^{-1}\right)$ & $34.41 \pm 5.48$ & $16.32 \pm 2.03$ & $45.68 \pm 2.07$ & $21.77 \pm 1.32$ & $51.55 \pm 3.69$ & $33.42 \pm 2.05$ & $73.74 \pm 2.98$ & $44.51 \pm 4.13$ \\
\hline$(\%)$ & $85.22 \pm 2.36$ & $92.99 \pm 1.57$ & $82.33 \pm 1.48$ & $90.06 \pm 0.75$ & $76.29 \pm 0.37$ & $85.64 \pm 1.12$ & $68.37 \pm 2.34$ & $80.88 \pm 1.24$ \\
\hline $\mathrm{TP}(\mathrm{m}$ & $0.26 \pm 0.02$ & $0.25 \pm 0.03$ & $0.32 \pm 0.02$ & $0.32 \pm 0.03$ & $0.38 \pm 0.01$ & $0.36 \pm 0.02$ & $0.42 \pm 0.01$ & $0.41 \pm 0.03$ \\
\hline$(\%)$ & $95.3 \pm 0.54$ & $95.56 \pm 0.38$ & $94.31 \pm 0.32$ & $94.30 \pm 0.18$ & $93.33 \pm 0.31$ & $93.68 \pm 0.45$ & $92.65 \pm 0.31$ & $92.81 \pm 0.54$ \\
\hline $\mathrm{NH}_{3}-\mathrm{N}\left(\mathrm{mg} \cdot \mathrm{L}^{-1}\right)$ & $5.43 \pm 1.03$ & $3.12 \pm 0.37$ & $7.11 \pm 0.87$ & $4.35 \pm 0.36$ & $9.46 \pm 0.49$ & $5.82 \pm 0.31$ & $13.36 \pm 1.55$ & $7.35 \pm 0.24$ \\
\hline$(\%)$ & $83.01 \pm 1.59$ & $91.64 \pm 0.93$ & $78.65 \pm 2.38$ & $88.78 \pm 1.23$ & $73.65 \pm 1.24$ & $83.79 \pm 0.89$ & $62.79 \pm 0.64$ & $79.53 \pm 0.17$ \\
\hline $\mathrm{TN}\left(\mathrm{mg} \cdot \mathrm{L}^{-1}\right)$ & $12.82 \pm 2.49$ & $8.13 \pm 1.21$ & $16.68 \pm 0.66$ & $10.45 \pm 0.21$ & $21.06 \pm 2.32$ & $11.67 \pm 1.01$ & $22.58 \pm 2.37$ & $14.03 \pm 0.31$ \\
\hline$(\%)$ & $62.77 \pm 0.36$ & $77.05 \pm 0.69$ & $58.09 \pm 0.22$ & $73.74 \pm 0.65$ & $47.09 \pm 1.29$ & $70.68 \pm 0.56$ & $43.22 \pm 0.98$ & $64.75 \pm 1.43$ \\
\hline
\end{tabular}



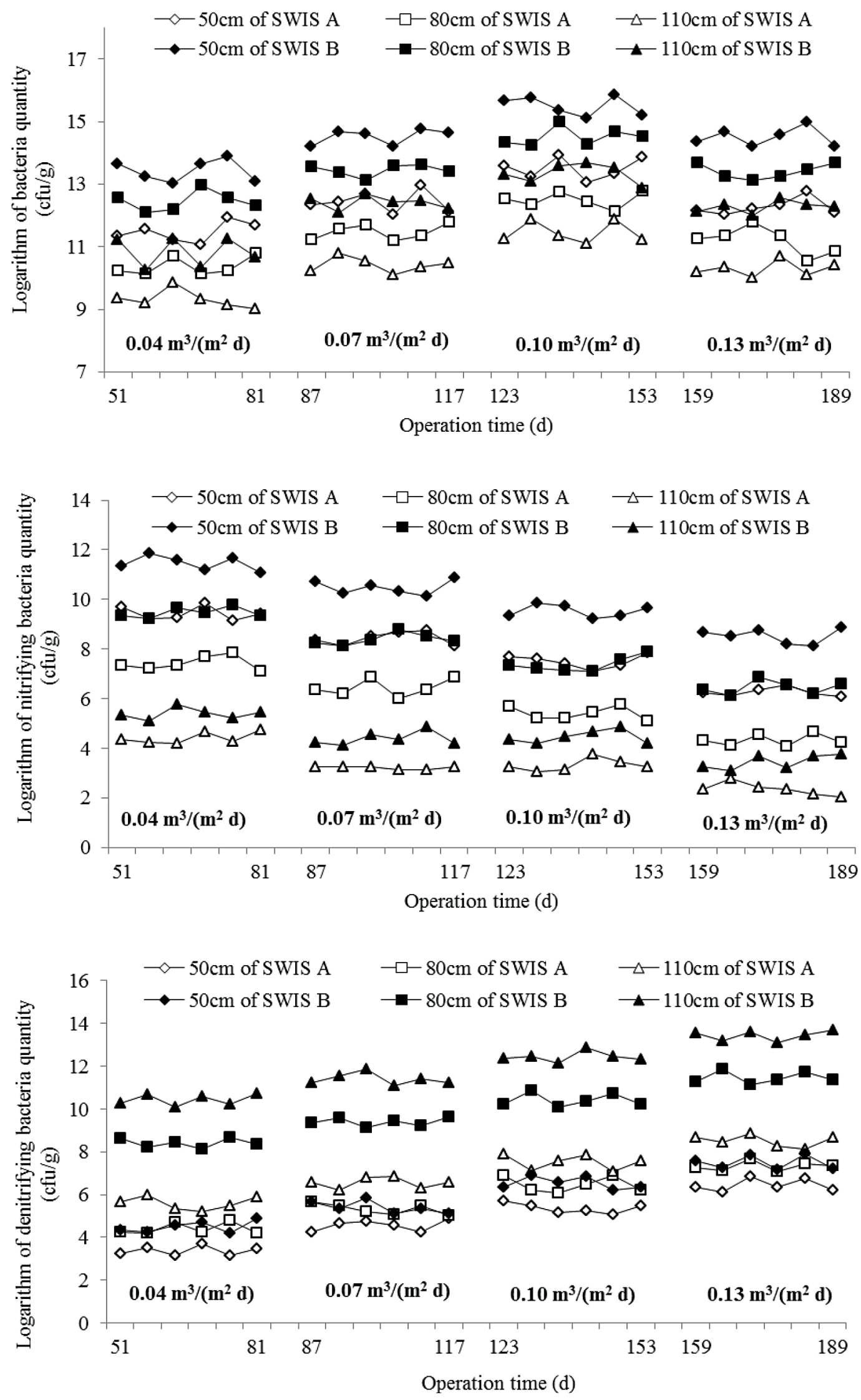

Figure 3

Distribution of bacteria, nitrifying and denitrifying bacteria in two SWISS 
type and quantity. The number of nitrifying bacteria in each layer of the matrix decreased with an increase in HLR. When HLR increased by $0.03 \mathrm{~m}^{3} \cdot \mathrm{m}^{-2} \cdot \mathrm{d}^{-1}$, the number of nitrifying bacteria decreased 10 -fold. These observations confirmed that HLR could affect the number of nitrifying bacteria in the following ways: Firstly, increasing hydraulic loading meant shortening hydraulic retention time, which led to a decrease in matrix oxidation-reduction potential, limiting the growth and reproduction of nitrifying bacteria (Li et al., 2011a; Yang et al., 2016). Secondly, high HLR accelerated matrix surface biological membrane replacement, which was not conducive to the growth and reproduction of nitrifying bacteria because of the long generation period of nitrifying bacteria. When HLR increased by $0.03 \mathrm{~m}^{3} \cdot \mathrm{m}^{-2} \cdot \mathrm{d}^{-1}$, the number of denitrifying bacteria increased 10 -fold at depths of 80 and $110 \mathrm{~cm}$. In this study, the number of nitrifying bacteria declined with increasing depth, whereas the number of denitrifying bacteria increased. Benefiting from the oxygen transferring availability of the upper matrix, the zones above $50 \mathrm{~cm}$ were the most effective nitrifying reaction region and the denitrifying bacteria were more active below $80 \mathrm{~cm}$. In an oxygen-limited environment, heterotrophic bacteria grow faster and may inhibit the development of nitrifying bacteria (Fan et al., 2013).

There was a highly significant difference in microbial quantity of the matrix between the two SWISs. At the same depth, the number of bacteria in SWIS B was 100 times higher than that in SWIS A under the same HLR. These results could further explain the higher removal of COD in SWIS B. Li et al. (201b) reported that nitrification and denitrification processes in the SWIS were affected by microbial biomass. Pan et al. (2013) reported that the number of nitrifying bacteria was positively correlated with $\mathrm{NH}_{3}-\mathrm{N}$ removal, and Li et al. (2011c) confirmed that the number of denitrifying bacteria were positively correlated with TN removal in SWIS. TN removal efficiency between $40 \%$ and $60 \%$ was reported, due to the denitrifying biomass usually being too low in a conventional brown earth and coal slag-based SWIS (Zou et al., 2009; Li et al., 2013). The number of nitrifying bacteria in SWIS B was 100 times higher than that in SWIS A at $50 \mathrm{~cm}$ depth, and the number of denitrifying bacteria in SWIS B was 100 times higher than that in SWIS A at depths of 80 and $110 \mathrm{~cm}$. These results could further explain the higher removal of $\mathrm{NH}_{3}-\mathrm{N}$ and TN in SWIS B. Zou et al. (2009) reported that microbial inoculums made with dewatered sludge (e.g. COD oxidizers, nitrifiers, denitrifiers) were added to conventional SWIS, which could improve pollutant removal rates.

This study suggests that using dewatered sludge as microbial inoculum of the matrix in brown earth areas is a reliable and innovative approach to achieve a shortened start-up period, waste recycling, high pollutant removal and strong hydraulic loading capacity.

\section{CONCLUSIONS}

The start-up period of brown earth-based SWIS inoculated with dewatered sludge was 28 days, 12 days shorter than that of the SWIS inoculated without dewatered sludge. The removal efficiencies for $\mathrm{COD}, \mathrm{NH}_{3}-\mathrm{N}$ and $\mathrm{TN}$ declined with increased HLR in both SWIS. COD, $\mathrm{NH}_{3}-\mathrm{N}$ and TN removal efficiencies for the SWIS using dewatered sludge as microbial inoculum were higher than that for the SWIS inoculated without dewatered sludge, under HLR of $0.04,0.07,0.1$ and $0.13 \mathrm{~m}^{3} \cdot \mathrm{m}^{-2} \cdot \mathrm{d}^{-1}$. Effluent COD, $\mathrm{NH}_{3}-\mathrm{N}$ and TN concentrations in the SWIS inoculated without dewatered sludge, under the
HLR of $0.1 \mathrm{~m}^{3} \cdot \mathrm{m}^{-2} \cdot \mathrm{d}^{-1}$ were simultaneously higher than the wastewater discharge limits for China of $50 \mathrm{mg} \cdot \mathrm{L}^{-1}, 8 \mathrm{mg} \cdot \mathrm{L}^{-1}$ and $15 \mathrm{mg} \cdot \mathrm{L}^{-1}$, respectively. Effluent concentrations of COD, $\mathrm{NH}_{3}-\mathrm{N}$ and $\mathrm{TN}$ in the SWIS inoculated with dewatered sludge were $44.51 \pm 4.13,7.35 \pm 0.24$ and $14.03 \pm 0.31 \mathrm{mg} \cdot \mathrm{L}^{-1}$ under the HLR of $0.13 \mathrm{~m}^{3} \cdot \mathrm{m}^{-2} \cdot \mathrm{d}^{-1}$. Under the same HLR, the number of bacteria, nitrifying bacteria and denitrifying bacteria in the SWIS inoculated with dewatered sludge were higher than that in the SWIS inoculated without dewatered sludge. The results suggest that dewatered sludge could be a good microbial inoculum to brown earth in light of start-up, pollutant removal and hydraulic loading capacity in SWIS.

\section{ACKNOWLEDGMENTS}

This research was financially supported by the National Natural Science Foundation of China (No. 41001321), (No. 41471394); Liaoning BaiQianWan Talents Program [2015(45)]; Natural Science Foundation of Liaoning (2015010585-301); and Ecology and Environment Research Centre Director Foundation of Shenyang Normal University (EERC-T-201501), (EERC-T-201601).

\section{REFERENCES}

AMERICAN PUBLIC HEALTH ASSOCIATION (APHA) (2003) Standard Methods for the Examination of Water and Wastewater. American Public Health Association/American Water Works Association/Water Environment Federation, Washington, DC.

ALEXANDER M and CLARK FE (1965) Nitrifying bacteria. In: Black CA (ed.) Methods of Soil Analysis, Part 2. American Society of Agronomy, Madison, WI. 1477 pp.

BROOKS AS, ROZENWALD MN, GEOHRING LD and LION LW (2000) Phosphorus removal by wollastonite: a constructed wetland substrate. Ecol. Eng. 15 121-132. https://doi.org/10.1016/ S0925-8574(99)00056-7

FAN JL, ZHANG B, ZHANG J, NGO HH, GUO WS, LIU FF, GUO YY and WU HM (2013) Intermittent aeration strategy to enhance organics and nitrogen removal in subsurface flow constructed wetlands. Bioresour. Technol. 141 117-122. https://doi.org/10.1016/j. biortech.2013.03.077

HSIEH CH, DAVIS AP and NEEDELMAN BA (2007) Nitrogen removal from urban storm water runoff through layered bioretention columns. Water Environ. Res. 79 2404-2411. https://doi. org/10.2175/106143007X183844

KIZIKAYA R (2008) Dehydrogenase activity in Lumbricus terrestris casts and surrounding soil affected by addition of different organic wastes and Zn. Bioresour. Technol. 99 946-953. https://doi. org/10.1016/j.biortech.2007.03.004

LEE SJ (2007) Enhanced dissolution of TCE in NAPL by TCEdegrading bacteria in wetland soils. J. Hazardous Mater. 145 17-22. https://doi.org/10.1016/j.jhazmat.2006.10.073

LI HB, LI YH, SUN TH and WANG X (2012) The use of a subsurface infiltration system in treating campus sewage under variable loading rates. Ecol. Eng. 38 105-109. https://doi.org/10.1016/j. ecoleng.2011.10.012

Li YH, Li HB, Pan J, Wang X, Sun TH (2012) Performance evaluation of subsurface wastewater infiltration system in treating domestic sewage. Water Sci. Technol. 65 713-720. https://doi.org/10.2166/ wst.2012.905

LI YH, LI HB, SUN TH and WANG X (2011a) Effects of hydraulic loading rate on pollutants removal by a deep subsurface wastewater infiltration system. Ecol. Eng. 37 1425-1429. https://doi. org/10.1016/j.ecoleng.2011.03.029

LI YH, LI HB, SUN TH and WANG X (2011b) Study on nitrogen removal enhanced by shunt distributing wastewater in a constructed subsurface infiltration system under intermittent operation mode. J. Hazardous Mater. 189 336-341. https://doi. org/10.1016/j.jhazmat.2011.02.039 
LI YH, LI HB, WANG H, WANG X, ZOU Y and SUN TH (2013) Comparison of the treatment performance of bio-substrate based and meadow brown soil based subsurface infiltration systems for domestic wastewater treatment. Water Sci. Technol. 67 506-513. https://doi.org/10.2166/wst.2012.576

LI YH, LI HB, WANG X and SUN TH (2011c) Changes in microbial populations and enzyme activities during nitrogen biodegradation of domestic sewage treatment in the subsurface wastewater infiltration system (SWIS). Bull. Environ. Contam. Toxicol. 87 (4) 431-435. https://doi.org/10.1007/s00128-011-0359-Z

LLORENS M, PEREZ-MARIN AB, AGUILAR MI, SAEZ J, ORTUNO JF and MESEGUER VF (2011) Nitrogen transformation in two subsurface infiltration systems at pilot scale. Ecol. Eng. 37 736-743. https://doi.org/10.1016/j.ecoleng.2010.06.033
PAN J, FEI HX, SONG SY, YUAN F and YU L (2015) Effects of intermittent aeration on pollutants removal in subsurface wastewater infiltration system. Bioresour. Technol. 191 327-331. https://doi.org/10.1016/j.biortech.2015.05.023

PAN J, YU L, LI GZ, HUANG LL and JIN HT (2013) Characteristics of microbial populations and enzyme activities in non-shunt and shunt subsurface wastewater infiltration systems during nitrogen removal. Ecol. Eng. 61 127-132. https://doi.org/10.1016/j. ecoleng.2013.09.025

YANG YQ, ZHAN X, WU SJ, KANG ML and GUO JA (2016) Effect of hydraulic loading rate on pollutant removal efficiency in subsurface infiltration system under intermittent operation and micro-power aeration. Bioresour. Technol. 205 174-182. https://doi.org/10.1016/j. biortech.2015.12.088 